\title{
方向性電磁鋼板を用いた螺旋コア
}

\author{
正員開道力（新日本製鐵） \\ Spiral Core made of Grain-oriented Electrical Steel Sheet \\ Chikara Kaido, Member (Nippon Steel Co.)
}

As a high performance motor core, spiral cores made of grain-oriented electrical steel sheets (G0) were developed. All the teeth directions are coincident with the 60 rolling directions (easy magnetization axis ) in the spiral cores. The 60 spiral cores have excellent properties, because the 60 has a very low iron loss and a very high permeability in the rolling direction. In the 60 spiral cores. the iron losses decrease to a quarter and the inductions are $0.2 \mathrm{~T}$ higher at $800 \mathrm{~A} / \mathrm{m}$ compared $m i$ th conventional spiral cores usually of SPCC. The thickness of conventional spiral cores generally changes, and the applications are limited to automobile alternator cores. The thickness of 60 spiral core scarcely changes during a spiral deformation. because the core sheets are deformed in the transverse direction to the rolling direction of $\mathrm{G} 0$. that is $\langle 110\rangle\{011\}$. and the $\langle 110\rangle\{011\}$ deformation of Fe does not bring about the sheet thickness. As the stiffness and the packing factor of a G0 spiral core are high in the sake of no thickness change. G0 spiral cores have high performance for motor cores.

キーワード：万向性電磁䤡板，螺旋コア，磁気回路，鉄損，磁束密度

\section{1. 楮言}

最近、電気自動車や工業用自動化機器等から家電機器ま での、あらゆるモー夕等の回転機において、小形軽量化、 高効率化の要求が高い。回転機の小形高出力化の為に、永 久磁石の高級化や導線占積率向上がなされ、コア素材に対 しては高位束密度化が要求されている。また、高効率化の 為には、高性能永久磁石や高磁束密度 (高透磁率) のコア 素材を用いることにより、励磁電流を低減（銅損低減）さ せるとともに、コア素材では鉄損を低減させることが重要 である。このようなコア素材への要求に対して、主なコア 素材である電磁鋼板は、銅板の蒚純度化や集合組織の改善 により、高磁束密度化（高透磁率化）や低鉄損化が行われ てきた。

一方、実用化を考えると、モー夕等の回転機の価格を低 くすることも重要である。そのため、回転機の製造コスト の削減のために、回枟機生産設備の自動化、省工程が重要 であり、また材料費㴥减の為には、電磁鉬板等のコア素材 のスクラップ低減が必要である。例えば、自動車の交流発 電㙨では、螺旋コアが使用され、生産ラインの自動化、ま たコア素材のスクラッブ低隇がなされている。

このような背景のもとに、回転機コアの高磁束密度化、 低鉄損化の為に、主要な従来コア材である無方向性電磁銅 板 (Non-oriented electrical steel sheet:NO) より、
極めて、高透磁率、低鉄損である方向性電磁鋼板（Grainoriented electrical steel sheet:GO）の磁化容易力向 を、コア性能を決定するコア磁路部に用いること等が検討 されている。スクラッフ低減のために、分割コア スクコア (巻きコア) ${ }^{2)}$ や螺旋コア (Spiral core）の検 討が加えられている。螺旋コアは、従来S P C C 材（磁気 特性的には無方向性) を用いて、自動車の交流発電機（才 ルタネータ）に使用されている。しかし、螺旋加工により 板厚が变化し、コアに占める電磁鋼板の比率 (占積率) が 低くなるため、コア磁気特性や機械的剛性が劣化する。従 って、蜾旋コアは板厚变化が小さい範冊に限られ、コアの 外周部（以後コアバック上呼ぶ。困 1 参照）の幅が㹟いも のしか、応用されていない。

今回、螺旋加工でコア板厚が殆ど变化せず、かつ設計磁 束密度を高く取れる螺旋コアとして、方向性電磁銈板を用 いた、コアの蒾の方向がすべて材料の磁化容易方向く10 $0>$ の圧延方向（L力问）てある方向性電磁鋼板蟔旋コア (以下、GO蜾旋コアと表示) を検討した。

\section{2．方向性電磁銅板を用いた螺唗コアの概要}

万向性電磁鍴板（GO）の磁化容易方向を活用したGO 螺旋コアの概念図を図 1に示す。GOは図2のように、王 延方向が磁化容易方向く $100>$ であり、このL方向の素 
材特性は、図3、図4のように、磁化特性および鉄損特性 が、従来の土な回転㙨コア素材に使用される無方向性電磁 鋼板（NO）より優れている。

G O螺旋コアは、このGOのL方向特性を活用するもの で、困2のように、加工前のコア片をGO素材より歯の方 问が力向になるように切り出す。その後、四1のように 螺旋巻き加工を行うと、歯が常に磁化容易方向く $100>$ である回転機コアができる。このGO蜾旋コアは、雨の磁 気特性が非常に優れているので、齿の特性が重要視される 多極回転機において、コア特性の改善効果が大きい。

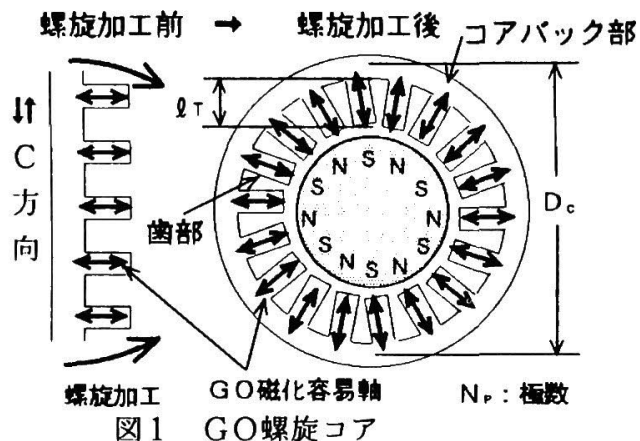

Fig. 1. G0 spiral core.

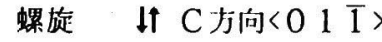

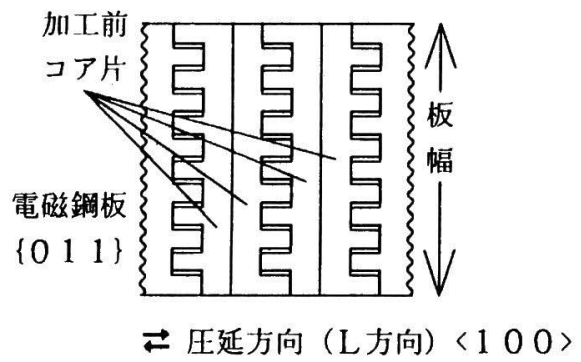

図2 GOと蜾旋加工前コア片

Fig. 2. G0 and core pieces before spiral deformation.

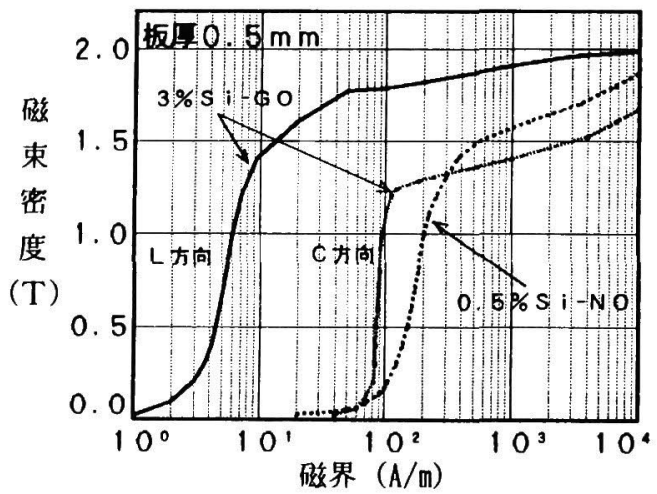

図3電磁鋼板素材のDC磁化特性

Fig. 3. DC magnetizing curves of electrical steel sheets.

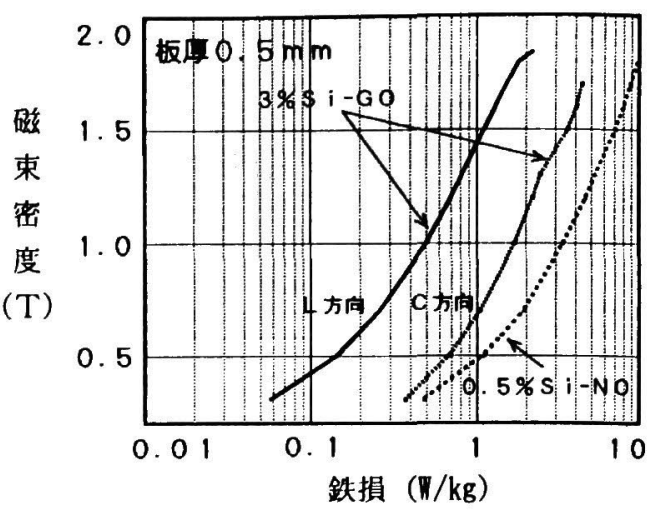

図4 電磁鋼板素材の鉄損特性

Fig. 4. Iron losses of electrical steel sheets at $50 \mathrm{~Hz}$.

実際に、製作したGO蜾旋コア（焼鈍後）を写真 1 に示 す。写真において、黒い部分が、方向性電磁鋼板GOの被 膜 $\left(S_{2}\right.$ 被膜 $\left.{ }^{3)}\right)$ であり、蜾旋加工により塑性変形してい る部分が白い部分（塑性変形により、被膜剝離した部分） である。

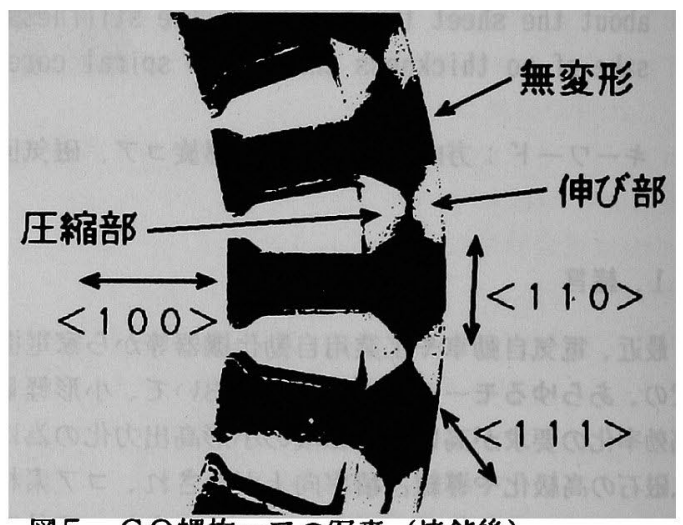

図5 GO螺旋コアの写真（焼鈍後）

Fig. 5. Photograghs of $\mathrm{GO}$ spiral cores.

\section{GO蜾旋コアの磁気回路特性}

GO蜾旋コアの磁気回路特性を、コアバック部と歯部に 分けて考える。

歯部は、GOのL方向（結晶方位 $<100>$ ）に対応す る。この部分は、前述のように、螺旋加工によって塑性変 形しないので、GOのL方向の優れた磁気特性がそのまま 反映される。従って、従来の無方向性電磁鋼板（NO） の場合より、磁化特性、鉄損特性ともに非常に良い。（図 3、図 4参照)

一方、コアバック部は、磁束の流れる円周方向がGOの C方向（結晶方位く０１１１）に対応する。この部分は図 1 のように、螺旋加工により塑性変形するので、コアバッ ク部の磁気特性はGOのC方向の素材特性とは異なり、望 性変形したGOのC方向の特性となる。そこで、図 1 と同 
しように、螺旋加さした菌がない円筒螺旋コア（円周方向 ：C方向）を試作して、通常の磁気测定を行うりング武料 （内径 $\mathrm{D}_{\mathrm{i}}=71 \mathrm{~mm} 、 \mathrm{D}_{0}=91 \mathrm{~mm} ）$ として磁気特性を測定をし、 等価的にコアバック部の磁気特性を評価した。使用した電 磁銅板は板厚 $0.5 \mathrm{~mm} 、 3 \% \mathrm{~S}$ i のGOで、比較材は板厚 $0.5 \mathrm{~mm} 、 0.5 \% \mathrm{~S}$ i のNO (50A $\left.1000^{4}\right)$ であ る。磁化特性と鉄損の測定結果を四6、図7に示す。GO 螺旋コアの場合、磁化特性は高磁界でNO螺旋コアより少 し少るが、全体的には同じ程度である。鉄損はGO蜾旋コ

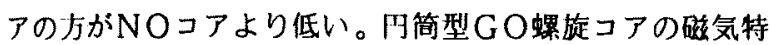
性は、接鈍すれば素材のC万方特性（図3、図4）と同程 度の值を示している。このように、GO螺旋コアにおける コアバック部の特性は、NOと比べて、同レベルである。

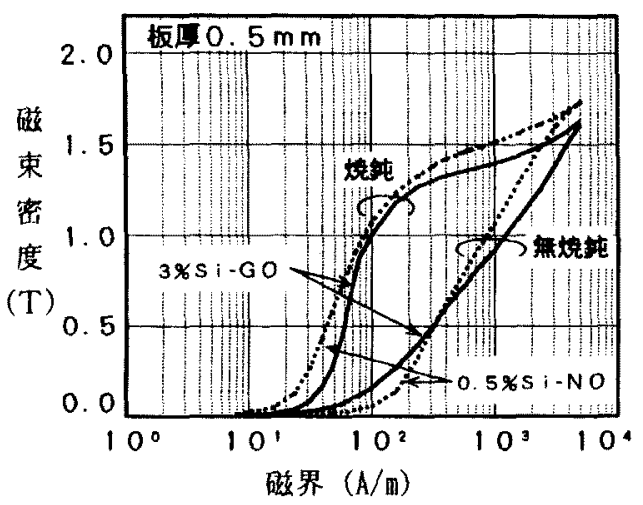

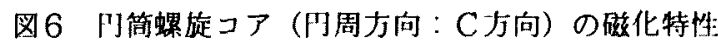

Fig. 6. Magnetizing force at cylindcal core

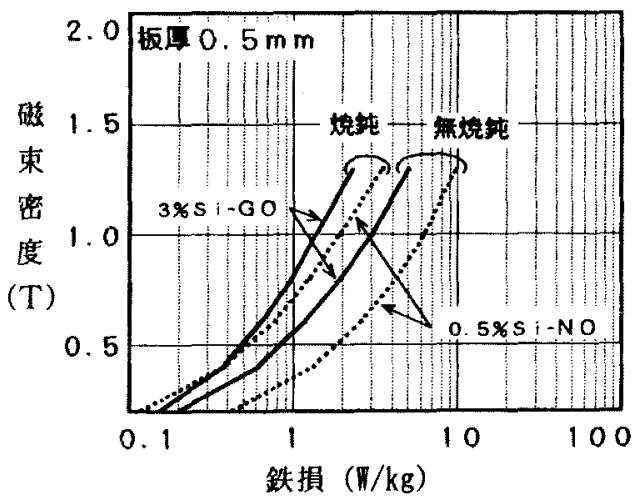

図7円简螺旋コア（円周力向：C力向）の鉄損特性

Fig. 7. Core loss at cylindcal core

次に、GO[粚 1.8 T、コアバック $1.35 \mathrm{~T}$ 設計］と NO [歯、コアバックとも $1.5 \mathrm{~T}$ 設計、焼鈍 $\left(750^{\circ} \mathrm{C}\right.$. 2時間) あり]について、菌付き蜾旋コアの励磁電流とコ ア鉄損を計算した。歯とコアバックの磁束密度に対応した 磁界と鉄損を、掬部の特性は図 3 、図4より、コアバック 部の特性は図 6、図7より求め、それそれの磁路長より全 朸磁電流と全鉄損を計算した。その結果を圀8に示す。縦
軸は焼鈍後のNO蜗旋コアにおける励磁電流や鉄損に対す るGO螺旋の励磁電流や鉄損の比率Kであり、横軸は、

$$
A=\frac{D_{c}}{N_{P} \ell_{\tau}}
$$

であり、Aは1極あたりのコアバック部磁路と橉の長さの 比率に比例する定数である。ここで、因 1 に示されるよう

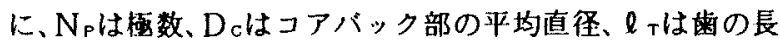
さである。

$\mathrm{GO}$ 螺旋コアの励眙電流は、烧鈍（800 $\mathrm{C} 、 2$ 時間） 後であれば、全てのAに対して、烧鈍後のNO螺旋コアよ りも低いことが分かる。ＧO螺旋コアが蜾旋加工のまま

（無焼鈍）の場合には、燋鈍後のNO螺旋コアに比べて、 $\mathrm{A}>0.2$ で、励磁電流は大きい。GO螺旋コアの鉄損は、 烧鈍前後とも、またA值に関わらずNO螺旋コアに比べ低 い。特に、多極コアのように、Aが小さい場合には、GO 蜾旋コアが優位であることが明かである。

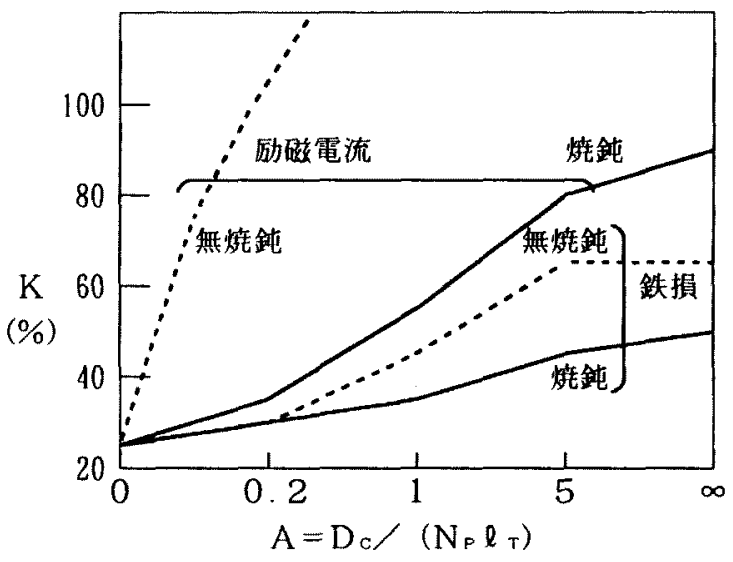

図8 来付縩旋コアの励磁電流、鉄損における $\mathrm{GO} / \mathrm{NO}$ の比 (理論計算)

Fig. 8. Percentages of exciting current and core loss of $\mathrm{GO}$ to those of $\mathrm{NO}$ in spiral cores with teeth. (theoretically calculated.)

螺旋コアを、実際の交流発電機（12極）の寸法で試作 し、烧鈍後の励磁特性を評晌した。コア磁気回路特性のみ を比較するため、螺旋コアと励磁フレーム（回転子／界磁 側に相当。フレーム材質はNO）を密着させて、即ち空隍 なしの固定子と回転子のような状態で、直流の励磁特性を 測定した。磁束密度は、歯部に探索巻線を巻き测定した。 磁界は、単純に螺旋コアの磁路辰で計算した。齿の方向が $<100>$ 方向のGOと、従来材（NO）の結果（磁束密 度が最も高い米で測定）を図9、図10に示す。

$\mathrm{GO}$ 螺旋コアの保磁力は、従来のNO螺旋コアの保磁力 の1/3〜1/5に減少した。保磁力は鉄損うちヒステリ シス損にほぼ比例するので、ヒステリシス損も $1 / 3 \sim 1$ ノ 5 になる。[鉄損のうち渦電流損は、一般に電気抵抗と 
板厚で決定されるので、蜾掟加工しても渦電流損はあまり 変化しない。ＧO蜾旋コアの傢束密度は、従来NO螦 旋より、1000〜2000A/mにおける磁束密度で、 $0.15 \sim 0.2 \mathrm{~T}$ 程、向上している。

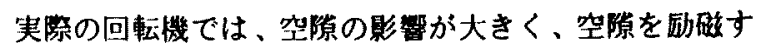
る励磁電流の力がコアを励磁する電流より大きい。そこ で、空隌約 $0.3 \mathrm{~mm}$ 、同様な実験を行い、同し励磁電

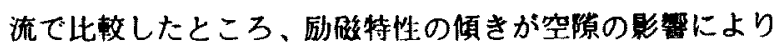
小さくなった為、保磁力は正確に測定できなかったが、G O螺旋コアと従来NO螺旋コアを磁束密度、保磁力につい て比较すると、はぼ同様の結果がった。

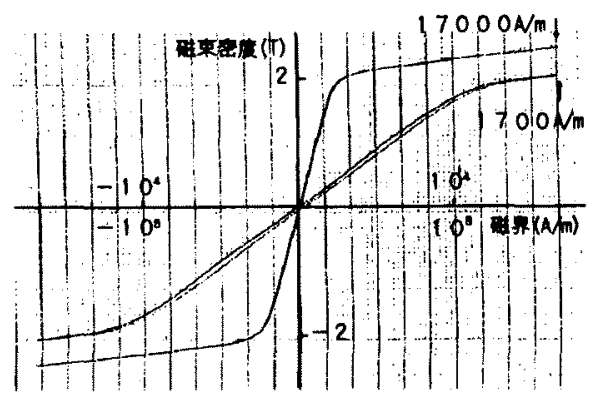

図9 GO螺旋コアの励酳特性

Fig. 9. Exciting force of 60 spiral core.

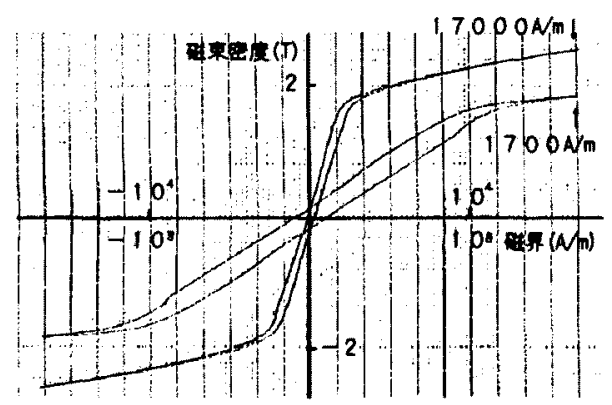

図10 従来螺旋コアの励磁特性

Fig. 10. Exciting force of conventional spiral core.

\section{4. 蟔续加工後の形状と形状限界}

蟔旋コアを、円周力向に枕力が加わらないように螺旋加 エした絬果、NOの板厚は蜾旋コアの外径で薄く、内径で 厚くなったが、歯の方向がく $100>て ゙ あ る G O$ 螺旋コア の場合では板厚の変化が殆ど見られなかった。この理由は 次の通りである。GO蜾旋コアではコアバック部が塑性変 版し、その变形はGOのC方向になる。ここで、引っ㖘り 盟性変形における板厚 $\mathrm{t}$ の变化と板幅Wの変化の比は、变 形前の板厚、板幅を $\mathrm{t}$ 。、 $\mathrm{W}_{0}$ 、变形前の板厚、板幅を $\mathrm{t}$ 、 W.として

$$
r \text { 値 }=\frac{\log \left(W_{0} / W_{1}\right)}{\log \left(t_{0} / t_{1}\right)}
$$

で表現されるr值 ${ }^{5)}$ で示され、GOのC方向 $[<100>$ \{0 $\left.\begin{array}{lll}0 & 1\end{array}\right\} の 90^{\circ}$ 方向] のr值は、図 11 より無限大て あるので、板厚は変化しないことが分かる。［GOは板面 が $\left\{\begin{array}{lll}0 & 1 & 1\end{array}\right\}$ 、L方向がく $100>$ である。] 即ち、GO のC方向の引っ張り望性変形では、材料内の变形滑り方向 がく $1111>$ で、鋼板面 $\left\{\begin{array}{lll}1 & 1 & 0\end{array}\right\}$ 内にある為、板厚は变 形しない。

このように、GO螺旋コアは、板厚が变化しないので、 GO螺旋コアではコアの占皘率は、従来の打ち抜きコアと 同じ程度になる。従来の無方向性電磁鋼板（NO）等によ る蜾旋コアでは、 $\mathrm{r}$ 值が 1.5〜2程度であり、コア材の板 厚が変化するので、占積率が低下し、回轱機の出力も低下 する。また、占皘率低下により、機械的剛性む低下するた め、回転機の振動や経音の原因にもなる。GO蜾旋コアて は、このような出力低下や騒音振動の問題は生じない。

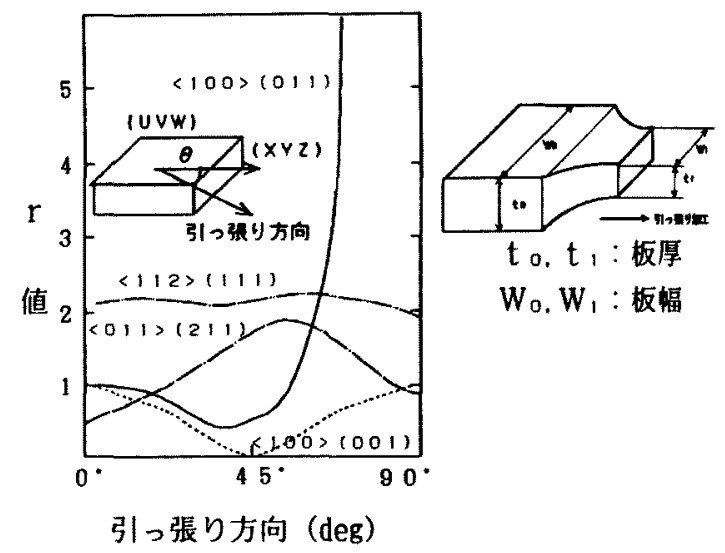

図 11 鉄の単結晶でのr值 ${ }^{5}$

Fig. 11. $r$-values in Fe single crystal

蜾旋コアのコアバック部板幅は、蜾旋加工前の板幅と比 较して、GO、NOとも殆ど変化なかった。これは、蜾旋 加工の場合、図 12 2ように引っ張り加工と圧樎加工が同 時に行われるためである。即ち、図中の $\mathrm{a}$ 部は円周方向に 延びるため幅方向は縮むが、b部は円周方向に圧樎される ため、幅方向は広がるので、この両部が打ち消し合って、 板幅は变化しない。

しかし、コアバック部板幅は変化しないが、コアバック 部の彬状は、図13のように変形する。GO蜾旋コアの場 合は、コアバックのスロット隣接部形状の変形量 $\Delta r n 、 \Delta$ $r \mathrm{c} \triangle \mathrm{r}$ oが次の式（3）で表せる。この変形は、NO媒 旋コアでは約半分になるが、同じ問題が生じる。しかし、 螺旋コアの最外径は变化しないので、実用上問影ないと推 定する。

$$
\Delta r_{1}, \Delta r_{c}, \Delta r_{0} \fallingdotseq \frac{W^{2}}{8 R}
$$

螺旋コアの形状を実腙にマイクロメーターやノギスを用 いて测定してみた。コアの外径 $80 \mathrm{~mm}$ 、内径 $60 \mathrm{~mm}$ 、 
外内径比 1.33の GO蜾旋コアの場合、コアの板厚变化 は板厚 $0.5 \mathrm{~mm}$ に対し、、イクロメーターて $5 \mu \mathrm{m}$ 以下で あった。(板厚0. $5 \mathrm{~mm}$ の O螺旋コアでは $40 \mu \mathrm{m}$ 板 厚が変化した。 一方、板幅变化は、GO、NO共に、 幅9.85 mmに対して、ノギス测定で50 $4 \mathrm{~m}$ 以下であっ た。このように、GO螺旋コアでは、コアバック部で多少 の帘形（雪み）はあるが、板厚、板幅の变化は殆と碓認さ れなかった。

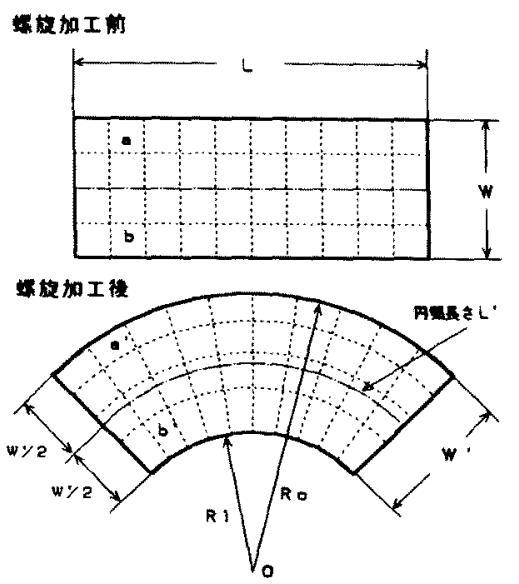

図12 螺旋加工によるメタルフロー

Fig. 12. Metal flow in spiral deformation

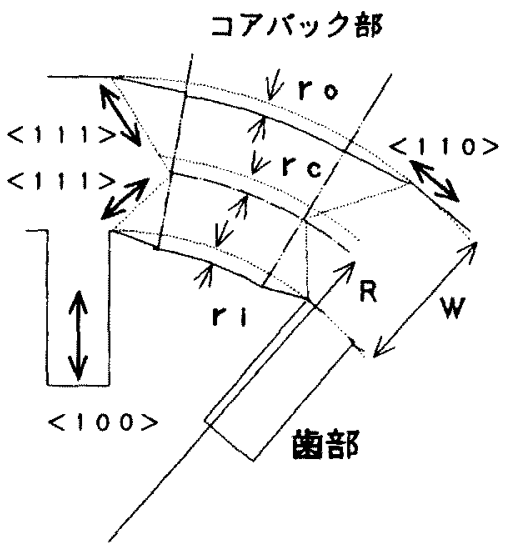

図13コアバック部变形

Fig. 13. Deformation at coreback.

GO蜾旋コアの形状限界を、円筒型コア（外径D。内 径D）の楊合で検討する。機械的な伸び(elongation)を $\varepsilon$ とし、压縮变形の限界を伸び $\varepsilon$ と等しいものと仮定する と、螺旋加工可能な範囲は、

$$
\frac{D_{0}}{D_{1}}<\frac{1+\varepsilon}{1-\varepsilon}
$$

となる。ここで、GOのC方向の伸びをは、表 1 より 30 $\sim 34 \% て ゙ 、 N O と$ 同程度であり、 $\varepsilon \fallingdotseq 0.3$ とすると、
次の式（5）となり、殆ど、全ての回転機コア（D。/D， <1.5）に対応できることが分かる。

$$
\frac{D_{0}}{D_{1}}<1.86
$$

一般な回転機の場合には、D。/Di<1.5であり、とが 0.2 以上であれぱGOの螺旋加工は可能であることがわ かる。

コアの幅 $W_{\mathrm{BY}}=\left(\mathrm{D}_{0}-\mathrm{D}_{1}\right) / 2$ に対して、蜾旋加工 可能な平均直径 $D=\left(D_{0}+D_{i}\right) / 2$ 住、

$$
\mathrm{D}>\frac{\mathrm{W}_{\mathrm{BY}}}{\varepsilon}
$$

となる。

一方、每付き蜾旋コア（雬の幅 $\mathrm{W}_{\mathrm{T}} 、$ 数 $\mathrm{N}_{\mathrm{T}}$ ）では、概算 的に

$$
\mathrm{D}>\frac{\mathrm{W}}{\varepsilon}+\frac{\mathrm{N}_{\mathrm{T}} \mathrm{W}_{\mathrm{T}}}{\pi}
$$

で、GO蜾旋コアの限界が表せる。

\begin{tabular}{|c|c|c|c|c|}
\hline 種 & 類 & \multicolumn{2}{|c|}{ 伸び (\%) } & \multirow{2}{*}{$\begin{array}{c}\begin{array}{c}\text { 占積率 } \\
(\%)\end{array} \\
\end{array}$} \\
\hline 記 号 & 板厚 (mm) & $\mathrm{L}$ & $\mathrm{C}$ & \\
\hline $\begin{array}{c}\mathrm{G} \\
\text { (犾エントコ） }\end{array}$ & $\begin{array}{l}0.23 \\
0.27 \\
0.30 \\
0.35\end{array}$ & $\begin{array}{r}5 \\
8 \\
10 \\
12\end{array}$ & $\begin{array}{ll}3 & 4 \\
3 & 0 \\
3 & 3 \\
3 & 2\end{array}$ & $\begin{array}{l}98.0 \\
98.5 \\
98.7 \\
98.7\end{array}$ \\
\hline $\begin{array}{c}\mathrm{P} \\
(\text { 犾冲顶・M化-) }\end{array}$ & $\begin{array}{l}0.23 \\
0.27 \\
0.30 \\
0.35\end{array}$ & $\begin{array}{r}5 \\
9 \\
8 \\
15\end{array}$ & $\begin{array}{ll}3 & 0 \\
3 & 3 \\
3 & 4 \\
3 & 3\end{array}$ & $\begin{array}{l}97.7 \\
98.1 \\
98.3 \\
98.5\end{array}$ \\
\hline $\begin{array}{r}\text { <参考> } 35 \mathrm{~A} 250 \\
50 \mathrm{~A} 470 \\
50 \mathrm{~A} 1000 \\
50 \mathrm{~A} 1300\end{array}$ & $\begin{array}{l}0.35 \\
0.50 \\
0.50 \\
0.50\end{array}$ & $\begin{array}{l}19 \\
32 \\
34 \\
35\end{array}$ & $\begin{array}{ll}2 & 1 \\
3 & 4 \\
3 & 4 \\
3 & 5\end{array}$ & $\begin{array}{ll}9 & 8.0 \\
9 & 8.5 \\
9 & 8.5 \\
9 & 8.5\end{array}$ \\
\hline
\end{tabular}

表 1 代表的な方向性電礈鋼板（3\%S i ）の伸び ${ }^{3)}$ Table 1. Elongation of grain-oriented electrical stee! sheets $(3 \% \mathrm{Si})$

GO螺旋コアにおける問題として、四2で明らかなよう に、GOのC方向（コアの円周方向に対応）の長さが、電 磁銅板（板厚 $\mathrm{t}$ ）の電䃍鋼板幅Ws る。電磁鋼板幅で対応できるGO蜾旋コアは、コアバック 部の平均直径D、コア厚さHとすると、

$$
\mathrm{DH}<\frac{\mathrm{t} \mathrm{W}_{\mathrm{ss}}}{\pi}
$$

である。 $\mathrm{t}=0.5 \mathrm{~mm} 、 \mathrm{~W}_{\mathrm{ss}}=1000 \mathrm{~mm}$ では、

$$
\mathrm{DH}<160 \mathrm{~mm}^{2}
$$


となり、小形回転機にしか適用できない。対策として、 GOのC方向スリット片を容接して、長い素材をつくり、 螺旋コアをつくるか、或いは 1 巻（1枚）の螺旋コアをつ くり、打ち抜きコアと同じように、積層する等が考えられ る。この1巻（1枚）の螺旋コア場合、

$$
\mathrm{D}<\frac{W_{\mathrm{ss}}}{\pi}
$$

であり、Wss $=1000 \mathrm{~mm}$ では、

$$
D<318 \mathrm{~mm}
$$

となり、ある程度大きい螺旋コアが可能である。当然、分 割コアにすれば、さらに大きい螺旋コアができる。

\section{5. 結言}

方向性電磁鋼板（GO）の压延方向（L方向）、即ち磁 化容易方向く $100>$ を米の力向に揃えたGO螺旋コアを 試作し、評侕した。

GO螺旋コアでの鉄損は、無方向性電磁鋼板（NO）の $50 \mathrm{~A} 1000$ の場合と比校し、歯部では 1／10以下に 激減でき、鉄損が高いコアバック部でも、50A1000 より低い。従って、GO螺旋コア全体では 50 A 1000 より 1/３以下に低減できる。（S P C C と比較すればさ らに改善率は大きい。）また、GOのL方向の磁束密度 では、800 A/mで1.9T以上で、無方向性電磁鋼板 の1.6T以下に比べてかなり高いので、GO螺旋コアの 使用条件によっては、かなりのコア磁束の増加、すなわち 回転機の高出力、小形軽量化が期待できる。

このように、GO螺旋コアは歯部に、磁気特性が極めて 優れているGOのL方向特性を活用するものなので、コア の磁気回路特性は、多極コアのように、コアバック部／歯 部の磁路長比が小さいほど大きく改善される。従って、回 転機の機種としては、2極や 4 極が主流である誘導機より、 8 極以上のブラシレスDCモータ等に適している。

また、このGO螺旋コアは、無力向性電磁鋼板を用いた 従来の螺旋コアと異なり、螺旋加工による板厚变化がない ので、占積率や凪性等の低減はない。さらに、従来の蜾旋 コアと闹様に、電磁鋼板のスクラップの低減も図2のよう に可能であり、回転機コアのコスト削減にもつながり、ま た回転機生産ラインの自動化も容易にできる。

以上のように、GO螺旋コアの優位性が確認された。し かし、実用化のためには、螺旋加工後の歪取り焼鈍などの 問題もある。中形機以上（コア励磁磁界が5000 A/mより低 い場合）では、雪取り焼鈍することにより特性が改善され るが、小型機（5000 A/m以上で使用）の場合は不要である と考えられる。被膜剥離や打ち抜きの問題も、従来のNO 皮膜塗布（有機／半有機系皮膜、L 被膜 ${ }^{3}$ 等）等をすれば 解消されると思われる。
このGO蜾旋コアの用途としては、小形軽量化、高効率 化が重要である分野が考えられる。例えば、電気自動車の 駆動モータをはじめ、工場等の省力化ロボットに使用され る高性能サーボモータ、さらには一般の高性能サーボモー タが考えられる。

最後に、この研究を行うにあたり、有益な御指導、御助 言して頂きました九州工業大学山畸二郎教授に深く感謝し ます。螺旋加工における塑性変形について討議して頂い た当社鉄鋼研究所銅材第一研究部利用技術タループに感謝 します。

(平成 7年 6月27日受付，平成 7年 8月30日再受付)

文献

（1）開道：電気学会研究会資料RM-94-59（1994）

（2）渡辺他：H5年電気学会全国大会N0.811

（3）新日鐵：「新日鐵の電磁鋼板」Cat. No. SC501

（4）日本工業規格：無方向性電磁鋼帯JIS C 2552-1986

（5）薄鋼板成形技術研究会（吉田監修）：プレス成形難 易ハンドブック（日刊工業新聞社。昭和6 2) P443

開道力（正員）1950年 9月 7日生まれ。48年九州

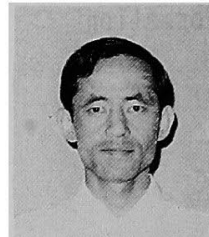
工業大学電子工学科卒業。50年 3 月東京工 業大学電子物理工学専攻修士課程修了。同 年新日本製鐵（株）入社。主として、電磁 鋼板をはじめとする磁性材料の磁気応用、 磁気物性及び磁気計測等の研究に従事。見 在、同社、鉄鎆研究所主幹研究員。 